\title{
Edible insects source of nutrients to improve food security worldwide
}

\author{
V. Melo-Ruiz, K. Sánchez-Herrera, M. García-Nuñez, R. Díaz-García and L. García \\ Departamento de Sistemas Biológicos, Universidad Autónoma Metropolitana, México
}

There is a very serious nutritional problem worldwide due to foodstuff deficiency affecting low income groups living in rural communities and slum zones at urban cities, however there are many sources of underutilize staple not enough investigated in spite of their enormous importance for a very large group of people ${ }^{(1)}$. Food security is a main concern of FAO, which is promoting several programs to reduce food insecurity worldwide by search underutilized food as insects. Insects reproduce at the faster rate, have higher protein conversion efficiency; they content all essential amino acids, polyunsaturated fatty acids and basic minerals in an adequate balance. Entomophagy cultural tradition since ancient times worldwide might be a good option to improve nutritional health to inhabitants of those regions ${ }^{(2)}$. This study assesses macronutrients of underutilized edible insects available and consumes in those regions and to inform people the benefits to health they provide and promote their intake on a daily diet ${ }^{(3)}$. Insects were obtained at local markets of the five countries studied except Mexico that samples were captured at insect habitat and macronutrient proteins, lipids, minerals, fiber and soluble carbohydrates assesses in dry basis. The insects analyzed are high in proteins macromolecules essential for life that also play a large part in the organoleptic properties of foods; high in lipids which have important functions in foods: culinary, physiological and nutritional. Their ability to carry odors and flavors and their contribution to palatability and texture in culinary presentation, are source of energy and many other functions; have a little fiber important in diet and soluble carbohydrates source of energy, minerals were not quantified individually.

\begin{tabular}{|c|c|c|c|c|c|c|c|}
\hline Insect name & Country & Water & Proteins & Lipids & Minerals & Fiber & Soluble carbohydrates \\
\hline Dragonfly & Indonesia & 52.11 & 51.65 & 25.78 & 4.25 & 4.16 & 14.16 \\
\hline Bloodwood Apple & Australia & 65.80 & 45.12 & 25.18 & 4.95 & 4.60 & 21.10 \\
\hline Zaza-mushi & Japan & 68.71 & 48.31 & 25.81 & 6.31 & 2.83 & 16.74 \\
\hline Cuetla & Mexico & 54.40 & 55.65 & 25.78 & 4.96 & 2.09 & 11.52 \\
\hline Banana grub & India & 60.92 & 45.11 & 25.83 & 5.52 & 1.05 & 22.49 \\
\hline
\end{tabular}

Results are presented in $\% \mathrm{~g} / 100 \mathrm{~g}$. Mean values in dry basis.

Nutritional value of insects is related to environment conditions, and might change due to biotic and abiotic of their habitat, the state of maturity also influence the nutritional value, availability are seasonal, but can be storage dry, without spoilage. Insects are well accepted by population offer a significant opportunity to merge traditional knowledge and modern science to improve human food security worldwide.

1. Castello T (1987) Presencia de la Comida Pre-hispánica en México. Banamex, México.

2. Hopkins J (2004) Extreme Cuisine Periplus Editions Ltd Singapore.

3. Melo V, García M, Sandoval H \& Calvo C (2011) Emir J Food Agric 23, 283-289. 